\title{
Diversity of Milks Other Than Cow, Sheep, Goat and Buffalo: In Terms of Nutrition and Technological Use
}

\author{
Marlon Numpaque ${ }^{1, a}$, Tuba Sanli ${ }^{2, b, *}$, Elif Ayse Anli2,c \\ ${ }^{1}$ Dairy Technology, Graduate School of Natural and Applied Sciences, Ankara University, 06110 Ankara, Turkey \\ ${ }^{2}$ Department of Dairy Technology, Agriculture Faculty, Ankara University, 06110 Ankara, Turkey \\ *Corresponding author
}

\begin{tabular}{l|l}
\hline A R T I C L E I N F O & A B S T R A C T \\
\hline Review Article & $\begin{array}{l}\text { The first introduction of human being with milk begins with human milk during infancy, continues } \\
\text { with very commonly with cow's milk and may be with other milk types during lifetime. Cow } \\
\text { breeding and utilizing its milk in nutrition is widespread in the world. There are particular species } \\
\text { common to their area such as donkey, camel, mare, yak and llama have an important share in milk } \\
\text { production in the world. Donkey milk has higher serum protein and lower casein content being } \\
\text { similar to human milk so regarded as a good and safer alternative for infants suffering from cow's } \\
\text { milk protein allergy. Mare milk is used as a therapeutic agent for the treatment of some metabolic } \\
\text { and allergic illnesses. It is generally consumed as fermented product. Llama milk contains higher } \\
\text { Accepted : } 18 / 11 / 2019 \\
\text { amounts of calcium and phosphorus than cow's milk. Camel milk has high vitamin and mineral } \\
\text { content and has claimed to have medicinal proteins. Its casein micelle size is larger naturally and it } \\
\text { has lower amount of } \kappa \text {-casein these cause difficulties in cheese making and affect curd quality. } \\
\text { Reindeer milk is an energy dense food with its high fat and high protein content when compared to } \\
\text { cow's milk. Its high protein content could make it suitable for protein supplementation. Its low } \\
\text { lactose content makes its consumption possible by lactose intolerance patients. Yak is richer in } \\
\text { almost all main nutritional components when compared with cow's milk. It can be used in cheese, } \\
\text { butter making and dried milk products. The objective of this review was to represent the composition } \\
\text { Milk } \\
\text { Different animal species } \\
\text { Milk composition } \\
\begin{array}{l}\text { Nutritional properties } \\
\text { Technological use }\end{array}\end{array}$ \\
nutrition and technological use.
\end{tabular}

\section{Introduction}

Cow is the most commonly used type of cattle for milk production in the world. Goat, sheep and buffalo are also used for milk production all around the world. However, in different regions of the world, other animal species such as donkey, mare, camel, yak, reindeer and llama have important share in milk consumption as well (Barlowska et al., 2011; Claeys et al., 2014). Somalia, Ethiopia, Kenya, Pakistan and Sudan are the countries using camel milk (Sakandar et al., 2018). Milk from species of camelids such as alpaca and llama is a protein source in Latin American highlands (El-Agamy, 2006). Mare milk is widely consumed in Mongolia (Pieszka et al., 2016) and yak milk is crucial in Tibetan diet (Li et al., 2010). Reindeer milk is popular in Russia and Sweden. The Sami people have been using reindeer milk for centuries. In recent years, donkey milk has attracted attention because of its similarity to human milk, especially regarding its protein composition
(Aspri et al., 2017; Madhusudan et al., 2017; Martini et al., 2017). In some European countries such as Belgium, France and Italy, donkey milk industry is developed and many progresses are supplied in clinical nutrition (Gastaldi, 2010).

Some extreme weather conditions like high/low temperatures, high/low humidity, low atmospheric pressure and/or other factors like limited food and water supply could prevent optimal milk production especially cow's milk which is indeed very common around the world. For these reasons in case of insufficiency in cow's milk supply, alternative milk sources should be found to substitute cow's milk (Claeys, 2014). In this review general information about milk from different species other than dairy animals (cow, buffalo, sheep and goat) and some nutritional and technological variations in their use depending on their composition are demonstrated. 


\section{Milk from Different Species}

\section{Donkey milk}

Donkey milk has been popular in ancient Egypt in that Cleopatra used donkey milk as a cosmetic material. Hypocrite suggested donkey milk for the treatment of infectious diseases and muscular pain (Gomez-Ruíz and Leche, 2011). The therapeutic properties of donkey milk made its use widespread in ancient times. Besides that in recent studies it is indicated that donkey milk can also be used as an alternative to breastfeeding in infants suffering from cow's milk protein allergy (CMPA) (Doreau et al., 2002; Guo et al., 2007; Gastaldi et al., 2010; Aspri et al., 2017; Madhusudan et al., 2017; Martini et al., 2018).

The milk-yield of donkey is very low when compared to cow. Daily $1 / 2$ liter of milk can be obtained from donkey at 3 times milking in average. This data indicates the rareness and high price of donkey milk. However, since donkey milk is superior with its antimicrobial properties that is; it is resistant to spoilage reactions, this could be regarded as a favorable property against its rareness (Gomez-Ruíz and Leche, 2011).

In composition donkey milk is similar to human milk with low protein and fat content and high lactose content (Table 1) and different than other dairy animals (Martini et al., 2018; Aspri et al., 2017). It is rich in essential amino acids (isoleucine, leucine, lysine, methionine, phenylalanine, threonine, tyrosine and valine) (Aspri et al., 2017). Although high amounts of polyunsaturated fatty acids (PUFA) mainly $\alpha$-linolenic acid and linoleic acid exist in donkey milk, it is characterized by low fat and energy values (Barlowska et al., 2011). According to studies, donkey milk possesses a number of components with biological activity and its proteins are precursors of different bioactive peptides (Nazzaro, 2010; Polidori and Vincenzetti, 2013; Aspri et al., 2017). Its antibacterial properties depend on existence of high amount of natural antimicrobial substances such as lactoferrin, lysozyme, lactoperoxidase and immunoglobulins (Guo et al., 2007; Aspri et al., 2017). Donkey milk induces nitric oxide (NO) release from Human Peripheral Blood Mononuclear Cells (PBMCs). That is very useful in the prevention of atherosclerosis, because NO is a strong vasodilator and an effective antimicrobial agent since pathogens and their products induce this illness (Madhusudan et al., 2017).

Although donkey is no regarded as a dairy animal, some countries such as Italy, Greece and France established dairy farms to increase milk production for valuable source in donkey milk-based cosmetic production (Doreau et al., 2002). The largest producer of donkey milk products in the world is Eurolactis, a Switzerland based company, producing special milk preparations for children suffering from CMPA, cosmetic products, soaps and products for lactose intolerant patients (Anonymous, 2019).

\section{Mare Milk}

Mare milk is one of the essential foodstuffs for the communities settled in Central Asia. It has a smooth and sweet taste and white-blue like color (Mazhitova et al., 2015). Mare milk is used as a therapeutic agent for the treatment of some metabolic and allergic illnesses (Salamon, 2009). It has been historically used for the treatment of tuberculosis in Russia and Mongolia (Mazhitova et al., 2015; Kushugulova et al., 2018). Furthermore, it is used in the treatment of chronic hepatitis in Mongolian medicine. Its anti-acid property make it available in treatment of peptic ulcer by preventing acid formation or regulation of acidity, especially in the stomach. Besides that, high contents of phospholipids and vitamin A are responsible for the therapeutic characteristics of mare's milk (Gastaldi, 2010; Kushugulova et al., 2018).

Mare's milk is more easily digested than cow's milk due to gastric juice when compared to cow's milk (Pieszka et al., 2016; Kushugulova et al., 2018). It belongs to albumin-milk group. The casein in mare's milk is more easily digested due to smaller micelle size of casein exist in mare's milk when compared to cows' milk. Small micelle size causes faster digestion times (that is 2 hours for mares milk and 3 to 5 hours for cow's milk) (Pieszka et al., 2016). Casein micelle size and structure causes coagulation characteristics of mare's milk differs from cow's milk resulting in soft and easily assimilating clot formation (Mazhitova et al., 2015).

Mare milk contains higher lactose than cow's milk. Its protein and ash contents are also lower than found in cow's milk and similar to human milk (Potočnik et al., 2011; Guri et al., 2016). This make its use suitable for the development of baby food products (Kushugulova et al., 2018). It could be tolerated by children with immunoglobulin E (IgE) mediated CMPA (Polidori and Vincenzetti, 2013). The average composition of mare milk is given in Table 1. Mare milk could be a promising milk source as donkey milk in that, it contains functional proteins and peptides that have immunological properties such as; lactoferrin, lactoperoxidase and lysozyme. The major obstacle regarding to mare's milk is its limited availability (Polidori and Vincenzetti, 2013).

Table 1 Major components of milk from various animal species*

\begin{tabular}{l|cccccc}
\hline & Total Dry Matter $(\%)$ & Protein $(\%)$ & Fat $(\%)$ & Lactose (\%) & Ash (\%) & Energy (kJ/l) \\
\hline Human & 12.42 & $0.9-1.7$ & 3.74 & 6.37 & 0.30 & 2843 \\
Mare & 9.42 & 1.90 & 1.30 & 6.90 & 0.36 & $1936-2050$ \\
Donkey & 11.04 & 1.72 & 0.38 & 6.88 & 0.47 & $1607-1803$ \\
Cow & 12.73 & 3.42 & 4.09 & 4.82 & 0.72 & $2709-2843$ \\
Sheep & 18.15 & 5.73 & 6.99 & 4.75 & 0.93 & $4038-4439$ \\
Goat & 13.32 & 3.26 & 4.07 & 4.51 & 0.85 & $2802-2894$ \\
Buffalo & $15.7-17.2$ & $2.7-4.7$ & $5.3-9.0$ & $3.2-4.9$ & $0.8-0.9$ & $4244-4779$ \\
Camel & 15.38 & 3.26 & 3.80 & 4.30 & 0.74 & $2410-3286$ \\
Llama & 13.45 & 4.20 & 4.70 & 5.90 & 0.80 & $2709-3358$ \\
Reindeer & 37.58 & 9.90 & 15.50 & 1.20 & 0.91 & $5541-8436$ \\
\hline Yak & $16.9-17.7$ & $4.9-5.3$ & $5.5-7.2$ & $4.5-5.0$ & $0.8-0.9$ & $3811-4295$ \\
\hline *(Adapted from; Dávila and Acevedo, 2007; Barlowska et al., 2011, Devle et al., 2012; Claeys et al., 2014) &
\end{tabular}




\section{Llama Milk}

Llamas are able to produce approximately 3-4 liters of milk per day. It is estimated that there are 3.7 million head of animals in South America and about a thousand hundred heads in other countries (Davila Acevedo, 2007). The llama milk is sweet and has a white color (Leyva et al., 2007). Llama milk also contains more Ca (170 mg $\left.100 \mathrm{~g}^{-1}\right)$ than cow's milk (122 mg $\left.100 \mathrm{~g}^{-1}\right)$. In addition to this llama, milk contains higher amounts of phosphorus and potassium (Davila Acevedo, 2007). However, it does not contain measurable amounts of $\beta$-lactoglobulin (Medina et al., 2004). The average composition of llama milk is given in Table 1.

\section{Camel Milk}

Camel is the most important livestock animal in arid and semi-arid areas of the world and camel's milk is a good source in human diet due to nutritional and medicinal properties (Kaskous and Pfaffl, 2017; Abrhaley and Leta, 2018). It is estimated that camel population is about 26.99 million around the world. More than $80 \%$ of the world's camel population is found in Africa. Ethiopia, Qatar, Kenya, Somalia, Saudi Arabia and Niger are the countries with the highest milk yield per animal (Singh et al., 2017). The period of lactation varies between 8-18 months and camels produce more milk for longer periods when compared to other animal species (Abrhaley and Leta, 2018).

Camel's milk is generally opaque white in color, has a faint sweetish odor and a little bit salty taste. The composition of camel milk varies according to location of the country and other factors like feeding conditions, seasonal variations, genetic factors and health status of animal (Kaskous and Pfaffl, 2017). The average composition of camel milk is given in Table 1.

Camel milk has low hypoallergenic properties since there is no $\beta$-lactoglobulin and there exists different $\beta$ casein structure that is observed in human milk (El-Agamy, 2006; Kaskous and Pfaffl, 2017; Abrhaley and Leta, 2018). The main whey protein is $\alpha$-lactalbumin in camel milk. The casein of camel milk is $\beta$-casein and $\kappa$-casein fractions is present in very low amounts or not so much. The ratio of casein/whey protein in camel milk is higher than present in cow's milk. This may explain why the coagulum of camel milk is softer than that of cow's milk (Singh et al. 2017).

Recently, bioactive components in camel milk are reported to possess potential medicinal properties like immunological and antibacterial activities (Sing et al., 2017; Kaskous and Pfaffl, 2017; Abrhaley and Leta, 2018). In addition to these camel milk and its components were also reported to have nutritional importance and potential health benefits especially in gastro intestinal health (Claeys et al., 2014; Kaskous and Praffl, 2017; Martini et al., 2018). Bioactive components of camel's milk are more heat stable than those in cow and buffalo milk. In camel milk heating at $100{ }^{\circ} \mathrm{C}$ for 30 minutes causes complete loss of antimicrobial activity (Claeys et al., 2014). Camel milk contains immunoglobulins, which are immune competent milk protein fractions, similar to those present in human milk (Barlowska et al., 2011).

\section{Reindeer Milk}

Reindeer milk is an energy dense food. The total fat in reindeer milk can be over 6 times as high as present in cow's milk and the protein content is 4 times as high as that is in cow's milk. The average composition of reindeer milk is given in Table 1. Due to its high protein and fat content, it can comfortably meet the growth and energy requirements for populations in challenging winter conditions. About $80 \%$ of the protein in reindeer milk is casein, similar to cow' milk. It contains $\beta$-lactoglobulin, but there is only partial crossreactivity between cow's and reindeer milks (Holland et al., 2002). Daily milk yield of reindeer is about 1.5 liters per day in the lactation period and that is very low when compared to cattle (Holland et al., 2002).

\section{Yak Milk}

Yak is also known as Tibetan cattle and almost 90\% of the yak population exist in China (Cui et al., 2016). Yak can survive in extreme climatic conditions such as Tibet (Li et al., 2010). Yak farming is done in small scale farms. Yak milk is richer than cow's milk in terms of total solids, protein and fat content (Table 1), and its composition is very similar to buffalo milk (Li et al., 2010). Yak milk contains almost twice as much as $\beta$-lactoglobulin $(6.23 \mathrm{~g}$ $\left.\mathrm{L}^{-1}\right)$ and lactoferrin $\left(0.67 \mathrm{~g} \mathrm{~L}^{-1}\right)$ is $2-6$ times more than present in cow's milk ( $\mathrm{Li}$ et al. 2010; Claeys et al, 2014). High carotene content of the yak milk make it suitable for butter making (Nikkhah, 2011).

Yak milk can be used in butter and cheese making and dried milk production (Nikkhah, 2011; Cui et al., 2016). High colloidal and soluble calcium and phosphorus in Yak milk have positive effect on curd stability, cutting time and yield (Nikkhah, 2011). Nepal has an important yak cheese industry and several types of cheeses such as Chauri and Yak Gruyère are currently produced (Nikkhah, 2011). There are cheese varieties are also made from yak milk especially in Mongolia, India and Pakistan (Wiener et al., 2003). In Tibet and Mongolia, Yak milk is used in butter and some traditional cheese manufacturing known as Yuzu, Tunas, Byaslag, Tarag and Aarul etc. (Anonymous, 2012; Tsakalidou and Khlonari, 2012). Yak-milk butter is more yellowish in colour depending on the high carotene content and described as delicious (Nikkhah, 2011). There are also several factories in China, Nepal and Mongolia producing dried yak milk for domestic consumption (Cui et al., 2016).

\section{Technological Use of Milk from Different Species Depending on Composition}

All mammals' milk contains same basic components like water, protein, fat, carbohydrates, vitamins and minerals. However, the compositions vary in ruminants (sheep, goat, cow, buffalo and camel) and non-ruminants (mare and donkey milk) (Devle et al., 2012). Within the same breed, milk composition may vary between animals due to factors as genetic, physiological lactation phase or milking interval, nutritional status (nutrients energy value and composition) and environmental conditions (breeding conditions, region and season) (Claeys et al., 2014). Basic milk compositions of various animal species are given in Table 1.

Among the basic components of milk, proteins are the major of nutrients having important technological significance in dairy. Milk protein content shows variability depending on the mammalian species. Casein and whey proteins are the two major categories of milk 
proteins. Casein comes from colloidal particles, called as micelles along with calcium and phosphate (Fox, 2001). The largest casein micelle is found in the camel milk (380 $\mathrm{nm}$ ) and that is higher than other species' milks such as micelle size in the cow's milk is around 150-180 nm. Smaller grains are reported to have higher casein content, while large grains have higher calcium and phosphate content. Coagulation time depends on the size of the mycelium and the smallest micelle coagulates faster. Therefore, the most suitable type of milk for cheese making is cow's milk (Yagil, 1982).

The total amino acid content is similar among species. However, there are significant differences in the amount of free amino acids that is proline (12\%) exist in camel milk, aspartic acid (10.4\%) exist in mare's milk with higher amounts among species and in human and donkey milk in similar amounts with $8.3 \%$ and $8.9 \%$, respectively. Lysine exist in reindeer milk with high levels $(9.2 \%)$ and the lowest lysine content $(3.1 \%)$ is observed in llama milk. Yak milk is richer in methionine $(3,1 \%)$ and phenylalanine content (5.0\%) among other species (Barlowska et al., 2011; Aspri et al., 2017). In addition, mare's milk contains low protein and similar amino acid composition as breast milk and does not cause risk for the development of renal function in infants (Mazhitova et al., 2015).

Especially, camel, llama and mare milks have higher immunoglobulin content than cow, sheep, goat and human milk. There is also a difference in immunoglobulin fractions between species. While IgG is dominant in colostrum of cow milk, it is known that the most important fraction of mare milk is IgA. However, the mare milk colostrum is also rich in both components (Claeys et al., 2014).

Donkey milk contains higher serum protein and lower casein content being similar to human milk. It has been reported that lysozyme content of donkey milk is 2 times higher than (about $1 \mathrm{~g} / \mathrm{L}$ ) that present in human milk. Due to presence of lysozyme as an antimicrobial system microorganism content of donkey milk is low (Guo et al., 2007; Martini et al., 2018). However, technological procedures could affect antimicrobial components to some extent. Lysozyme preserves its activity although milk is processed into powder or milk is frozen. Heating at $63^{\circ} \mathrm{C}$ for 30 minutes and HTST pasteurization $\left(72^{\circ} \mathrm{C}\right.$ for $\left.15 \mathrm{~s}\right)$ did not adversely affect the immunoglobulin content ( $\operatorname{IgA}$, IgG) (Aspri et al., 2017).

Mare milk is generally consumed as fermented product, which is called in some countries Kumis and in Mongolia as Ayrag (Kushugulova et al., 2018). Kumis is a traditional product, fermented raw mare's milk, in the Kazakhstan and is known by Kirghiz people for its nutritional and therapeutic properties (Mazhitova, 2015). An alternative drink to Kumis is known as Ayrag and it is widely consumed in Mongolia. Several European companies use mare milk for skin cleaning products such as; creams, foams, soaps, shampoo and other cosmetic products (Di Cagno et al., 2004; Mazhitova, 2015).

Camel milk casein differs in terms of composition and micelle size when compared to cow's milk casein. The larger size of caseins (380 nm) associated with camel milk nature and lower amount of $\kappa$-casein (about $5 \%$ of total casein) causes reduction in the ability of coagulation and the firmness of the curd (Sakandar et al., 2018). In the literature, it has been reported that making cheese from camel milk is difficult because of problems associated with production including long coagulation time, soft and weak curd formation causing difficulties in separation of whey (Ramet, 2001; Benkerroum et al. 2011; Konuspayeva et al. 2014; Sakandar et al., 2018). A developed coagulating agent called "camifloc, a vegetable origin rennet, solves the problem of long coagulation times in camel-milk cheese production. In addition to that very few soft cheeses made from camel milk have properties of fresh cheese with high moisture content. Cheese factories in the former Soviet States were known to produce spicy cheese from camel milk (Yagil, 1982). In the USA, a product named "Mauritania Brie" which is similar to mozzarella and white cheese was developed from camel milk. In the United Arab Emirates, it is known that a company named "Camelicious" produces ice cream and chocolate from camel milk (Tsakalidou and Khlonari, 2012). Camel milk is especially pasteurized and can be consumed as drinking milk or fermented product. Fermented products of camel's milk vary according to the method of processing and known as different names such as Kefir (Caucasia), Matzoon (Armenia), Dahdi (India), Gioddu (Sardinia), Yoghurt (Bulgaria), Lehben (Israel, Saudi Arabia and Egypt) (Yagil, 1982) and Lehban (Syria and Egypt), Tarag (Mongolia) (Sakandar et al., 2018). However, there exists some fermented raw camel milk products like Gariss (Sudan) and Suusac (Kenya and Somali) (Singh et al., 2017).

Reindeer milk is known to be suitable for fresh milk and yogurt production (Anonymous, 2012). Reindeer milk may be suitable as a protein supplement, especially for athletes. The high protein content also means a higher content of amino acids that are 2-6 times more than found in cow's milk (Holland et al., 2002; Gjostein et al., 2004). Reindeer contains high levels of water and fat soluble vitamins and low levels of oligosaccharides. Use of reindeer milk in treatment of digestive problems is reported and its colostrum is used as special food for children (Taufik et al., 2014).

Lipids are important milk components with regard to nutrition, physiology and technologically. Milk fat synthesized in the breast cells is in the form of globules ranging in diameter from about 0.1 to $18 \mu \mathrm{m}$. The size of fat globules affects the dispersing state of milk fat, which is important for digestibility. This lower size of the globules indicates that a larger surface available for the lipase action (D'urso, 2008; Martini et al., 2018). Milk fat concentration and milk fat globule size varies according to animal species. The smallest globules exit in donkey (1.92 $\mu \mathrm{m})$, camel $(2.99 \mu \mathrm{m})$ and goat $(3.2 \mu \mathrm{m})$ and the largest globules exist in buffalo $(8.7 \mu \mathrm{m})$. Yak milk is known to be suitable for obtaining milk cream due to its high fat globule diameter (5-6 $\mu \mathrm{m})$ (Nikkhah, 2011). The lower fat globule size and digestibility relation make donkey, camel and goat milks suitable for use in human nutrition (D'urso, 2008; Barslowska et al., 2011; Martini et al., 2018). Low fat content causes low calorie that is lower energy in donkey and mare milk when compared to milks of other species (Martini et al., 2018).

In terms of milk fat composition, cow, sheep, goat and human milk consists of $97-98 \%$ triglycerides and it exists in ratio of $80-85 \%$ in donkey and mare's milk (Malacarne et al., 2002; El-Agamy, 2006). The feeding mechanism and the fatty acid synthesis ability are the determining factors 
of milk fatty acid composition (Salamon, 2009). The mean value of oleic acid was the lowest $(1.2 \%)$ in donkey milk compared to other types of milk (average 12\%) (Barlowska et al., 2011). In terms of saturated fatty acids (SFA) content, human milk and mare's milk's amounts are lower than the other species' milks and for PUFA donkey milk and mare's milk contain similar and higher amounts when compared to other types of milks (Gastaldi, 2010; Claeys et al., 2014; Kaskous and Pfaffl, 2017). In reindeer milk main fatty acids (FA) are palmitic, oleic, stearic and miristic acids (Holland et al., 2002). Mare milk is reported to be rich in unsaturated and short chain fatty acids when compared to cow's milk and plays an important role in nutrition, especially; FAs such as capric, lauric, caprylic acid (Salamon, 2009; Claeys et al., 2014). The short chain fatty acids of camel milk (C4-C8) are lower than cow's and other ruminant's milk (Kaskous and Pffal, 2017). The camel milk fat contains lower concentration of carotene so appears distinctly white in color (Sakandar et al., 2018). The fat disperse in similar manner in cow's and in camel's milk. However, since camel milk contains lower levels of agglutinins (such as cryoglobulin), creaming occurs in lower rate. Technologically, in butter production from camel milk, higher churning temperatures are required due to high melting point of camel milk fat $\left(20-25^{\circ} \mathrm{C}\right)$ by traditional methods when compared to require for butter from cow's milk $\left(8-12^{\circ} \mathrm{C}\right)$ (Al haj and Kanhal, 2010).

The fatty acids composition of Yak milk are similar to those present in cow and buffalo milks. Saturated fatty acids accounts for about $65 \%$ in total FA in Yak milk. The short chain fatty acids content (C4-C10) is low in yak milk (Barlowska et al., 2014). In China, Kyrgyzstan, Nepal and Bhutan, that is Tibetan plateau, yak butter is widely consumed domestically.

The major carbohydrate in all milk types is lactose and it is synthesized from glucose and galactose (Davila Acevedo, 2007; Kaskous and Pfaffl, 2017). The presence of high lactose enhances flavor, while at the same time it helps the development of probiotic microorganisms and intestinal calcium absorption (Davila Acevedo, 2007). As shown in Table 1, the lactose contents of human, mare and donkey milk are similar and higher than other types of milk (Potočnik et al., 2011; Martini et al., 2017). Among the milk types considered lactose content in reindeer is low, that is nearly half of the amount found in cow's milk. This property could represent that reindeer milk can be a good alternative for lactose intolerant patients (Taufik et al., 2014). The Sami people are intolerant of lactose; reindeer milk is a part of their diet (Holland et al., 2002). Similarly, camel milk considered as an alternative for individuals intolerant to lactose (Kaskous and Pfaffl 2017; Abrhaley and Leta, 2018). In reported studies remarking suitability of camel's milk for lactose intolerant people suffering from this disorder, easily digest the lactose present in camel's milk although lactose exist in camel milk in similar amounts in cow's milk. The lower lactose intolerance of camel milk could explain with its high L-lactate content, unlike cow's milk, rich in D-Lactate (Kaskous and Pfaffl, 2017). Donkey milk, with its high lactose content it is also not suitable for lactose intolerant people (Perna et al., 2015) but is also a valuable resource in terms of the galactose content required for the development of the nervous system (Tafaro et al., 2007). Researches indicated that with high lactose content, it is possible to use donkey milk in fermented dairy products with enhanced therapeutic characteristics (Perna et al., 2015).

Milk is a valuable source of both water and fat-soluble vitamins. The total vitamin content of milk is highly variable and depends on lactation status and nutritional regime. It is reported that in donkey's milk vitamin $\mathrm{C}$ (about $5700 \mu \mathrm{g} / 100 \mathrm{ml}$ ) exist in similar amounts in human's milk (about $5600 \mu \mathrm{g} / 100 \mathrm{ml}$ ) and higher than that present in cow's milk $(1500 \mu \mathrm{g} / 100 \mathrm{ml})$. Vitamin D in donkey milk (about $2.3 \mu \mathrm{g} / 100 \mathrm{ml}$ ) exist in significantly higher amounts than human's milk and cow's milk in which they exist in similar amounts about $0.03 \mu \mathrm{g} / 100 \mathrm{ml}$ (Martini et al. 2017). Camel milk could become an important source of vitamin C with $3416 \mu \mathrm{g} / 100 \mathrm{ml}$ content (Nikkhah, 2011; Sakandar et al., 2018). The vitamin A content in camel milk is reported to be lower than that of cow's milk (Kaskous and Pfaffl 2017).

Milk is an important source of minerals especially calcium, sodium, potassium, magnesium, chlorides and phosphorus. Minerals participate in numerous physiological functions (Barlowska et al., 2011; Claeys et al., 2014). Donkey's milk mineral content changes in average of $0.36 \%$ but significantly lower than cow's milk (about $0.76 \%$ ). Moreover, there is less calcium content in donkey milk lower than the other milk types (Martini et al., 2018). The mineral content of camel milk is varies around 0.60 to $0.90 \%$. In camel milk calcium, magnesium and phosphorus contents are similar to cow's milk (Singh et al., 2017; Sakandar et al., 2018). In addition, camel milk is a rich source of chloride $(\mathrm{Cl})$ due to the forage eaten by camels, which might be the reason of salty taste in camel's milk (Singh et al., 2017). Reindeer milk has high mineral content (358 mg of calcium, $158 \mathrm{mg}$ of sodium, $150 \mathrm{mg}$ of phosphorus in $100 \mathrm{~mL}$ milk) similar to that of cow's milk (Gjostein et al., 2004).

\section{Conclusion}

Cow is the most important animal species in the world for milk production. Cow's milk can not be replaced with another milk type in terms of technological properties and nutritional value. However, other types of milk are used locally, and their use should be encouraged in situations where not all nutritional needs can be met by cow or human milk. Donkey and mare's milk could be a good and safer alternative, compared to other types of milk, for children with CMPA, when breastfeeding is not suitable. Camel milk is a valuable vitamin $C$ source especially in desert district where fruits and vegetables are inadequate. Fresh and fermented camel milk was reported to provide particular health benefits to the consumer depending on the availability of bioactive substances in milk. Yak milk's composition varies according to season and breed so in technological practices in yak-based milk products this variation in composition should be considered. Reindeer is a dairy animal that can survive at extreme cold climatic conditions supplying milk demand in this region. Llama has a cultural importance in South American countries but it is kept mainly for its fiber and meat. Llama milk is also consumed locally and its wide production for human use as a milk source is not seem to be possible. Many different species' milk products have been standardized and 
commercialized in some parts of the world. Clinical studies are needed in order to confirm and update the potential health properties of milks from alternative species.

\section{References}

Al haj OA., Kanhal HA. 2010. Compositional, technological and nutritional aspects of dromedary camel milk. International Dairy Journal, 20 (2): 811-821. DOI: 10.1016 /j.idairyj.2010.04.003.

Anonymous. 2019. (http://www.eurolactis.com/en/press.html). Access date: 15.02.2019.

Anonymous. 2012. IDF World Dairy Summit 2012. Processing of Non-Cow's Milk -Technological Challenges and Economic PerspectivesCape Town, South Africa 4-8 November 2012.

Aspri M, Economou N, Papademas P. 2017. Donkey milk: An overview on functionality, technology, and future prospects. Food Review International, 3: 316-333. DOI:10.1080 /87559129.2016.1175014.

Abrhaley A, Leta S. 2018. Medicinal value of camel milk and meat. Journal of Applied Animal Research, 46: 552-558. DOI: 10.1080/09712119.2017.1357562.

Barlowska J, Szwajkowska M, Litwinczuk Z, Krol, J. 2011. Nutritional value and technological suitability of milk from various animal species used for dairy production. Comprehensive Reviews in Food Science and Food Safety. 10: 291-302. DOI: 10.1111/j.1541-4337.2011.00163.x.

Benkerroum N, Dehhaoui M, El Fayq A, Tlaiha R. 2011. The effect of concentration of chymosin on the yield and sensory properties of camel cheese on its microbiological quality. International Journal of Dairy Technology. 64(2): 232-239. DOI: $10.1111 /$ j.1471-0307.2010.00662.x.

Claeys WL, Verraes C, Cardoen S, De Block J, Huyghebaert A, Raes K, Dewettinck K, Herman L. 2014. Consumption of raw or heated milk from different species: An evaluation of the nutritional and potential health benefits. Food Control, 42: 188-20. DOI: 10.1016/j.foodcont.2014.01.045.

Cui GX, Tuan F, Degen AA, Liu SM, Zhou JW, Shang ZH, Ding LM, Mi JD, Wei XH, Long RJ. 2016. Composition of the milk of yaks raised at different altitudes on the QinghaiTibetan Plateau. International Dairy Journal, 59: 29-35. DOI:dx.doi.org/10.1016/j.idairyj.2016.02.046.

Dávila Acevedo MJ. 2007. Consumo de la leche de llama (Lama glama) en los Andes Peruanos. Consumption of the llama (Lama glama) milk in Peruvian Andes. Ciencia y Desarrollo 8:5-18. DOI:10.21503/CienciayDesarrollo.2007.v8.0.

Devle H, Vetti I, Naess-Andresen C, Rukke E, Vegarud, G, Ekeberg, D. 2012. A comparative study of fatty acid profiles in ruminant and non-ruminant milk. European Journal of Lipid Science and Technology, 114(9): 1036-1043. DOI: 10.1002/ejlt.201100333

Di Cagno R, Tamborrino A, Gallo G, Leone C, De Angelis M, Faccia M, Amirante P, Marco Gobbetti M. 2004. Uses of mares' milk in manufacture of fermented milks. International Dairy Journal, 14 (9): 767-775. DOI: 10.1016/j.idairyj. 2004.02.005.

D’Urso S., Cutrignelli MI, Calabrò S, Bovera F, Tudisco R, Piccolo V, Infascelli F. 2008. Influence of pasture on fatty acid profile of goat milk. Journal of Animal Physiology and Animal Nutrition, 92(3): 405-10. DOI: 10.1111/j.14390396.2008.00824.x.

Doreau M, Gaillard J, Chobert J, Léonil L, Egito A, Haertlé T. 2002 Composition of mare and donkey milk fatty acids and proteins and consequences on milk utilization. Proceeding of 4 th Congress. New Findings in Equine Practice. Campobasso (Italy), 11-12 July. pp: 51-71.

El-Agamy I. 2006. Camel milk production and utilization. In book: (Park Y and Haenlein, G). Handbook of Milk of NonBovine Mammals. Oxford. Blackwell Publishing. pp:297. 13: 978-0-8138-2051-4.
Fox PF. 2001. Milk proteins as food ingredients. International Journal of Dairy Technology, 54 (2): 41-55. DOI: 10.1046 /j.1471-0307.2001.00014.

Gastaldi D, Bertino E, Monti G, Baro C, Fabris C, Lezo A, Medana C, Baiocchi C, Mussap M, Galvano F, Conti A. 2010. Donkey's milk detailed lipid composition. Frontiers in Bioscience, E2: 537-546.

Gjøstein H, Holand O, Weladji R. 2004. Milk production and composition in reindeer (Rangifertarandus): effect of lactational stage. Comparative Biochemistry and Physiology Part A, 137: 649-656. DOI: 10.1016/j.cbpb.2004.01.002.

Guo HY, Pang K, Zhang XY, Zhao L, Chen SW, Dong ML. 2007.Composition, physicochemical properties, nitrogen fraction distribution, and amino acid profile of donkey milk. Journal of Dairy Science, 90: 1635-1643. DOI: 10.3168 /jds.2006-600.

Guri A, Paligot M, Crevecoeur S, Piedboeuf B, Claes J, Daube G, Corredig M, Griffiths MW, Delcenserie V. 2016. In vitro screening of mare's milk antimicrobial effect and antiproliverative activity. FEM Microbiology Letters, 363 (2): 1-7. DOI: 10.1093/femsle/fnv234.

Gomez-Ruíz T, Leche B. 2011. Composición nutricional y bioactividad. Alimentacion, Nutricion Y Salud, 18: 10-15.

Holand Ø, Gjøstein H, Aikio P, Nieminen M, White RG. 2002. Traditional reindeer milking and prospects of developing reindeer farming as a niche based production. Encyclopedia Dairy Science, 637-643.

Kaskous S, Pfaffl MW. 2017. Bioactive properties of minor camel milk ingredients-An overview. Journal of Camel Practice and Research, 24: 15-26. DOI:10.5958/22778934.2017.00003.0.

Konuspayeva G, Camier B, Gaucheron F, Faye B. 2014. Some parameters to process camel milk into cheese. Emirates Journal of Food and Agriculture, 26 (4): 354-358. DOI: 10.9755/ejfa.v26i4.17277.

Kushugulova A, Kozhakhmetov S, Sattybayeva R, Nurgozhina A, Ziyat A, Yadav H, Marotta F. 2018. Mare's milk as a prospective functional product. Functional Foods in Health and Disease, 8 (11): 537-543. DOI: 10.31989/ffhd.v8i11.528.

Li H, Dong A, Wang J, Li Q, He S, Maubois JL. 2010. Protein composition of yak milk. Dairy Science Technology, 90 (1): 111-117. DOI: $10.1051 / \mathrm{dst} / 2009048$.

Leyva V, Gonzales R, Garcia W, Gavidia C, Ticona D. 2007. Efecto de la alimentación de llamasseleccionadas para producción de carne en la producciónláctea y crecimiento de sus crías. APPA - ALPA - Peru. 1-7.

Madhusudan NC, Ramachandra CT, Udaykumar N, Sharnagouda H, Nagraj N, Jagjivan R. 2017. Composition, characteristics, nutritional value and health benefits of donkey milk-A review. HAL archives-ouvertes.fr.hal-01538532.

Malacarne M, Martuzzi F, Summer A, Mariani P. 2002. Review: protein and fat composition of mare's milk: some nutritional remarks with reference to human and cow's milk. International Dairy Journal, 12: 869-877. 10.1016/j.sbspro. 2015.06.479.

Martini M, Altomonte I, Licitra R, Salari F. 2017. Nutritional and nutraceutical quality of donkey milk. Journal of Equine Veterinary Science, 65: 33-37. 10.1016/j.jevs.2017.10.020.

Martini M, Altomonte N, Licitra R, Salari F. 2018. Nutritional and Quality of Donkey Milk. Journal of Equine Veterinary Milk, 65:33-37. DOI: 10.1016/j.jevs.2017.10.020.

Mazhitova A, Kulmyrzaeva A, Ozbekovaa Z, Bodosheva A. 2015. Amino acid and fatty acid profile of the mare's milk produced on suusamyr pastures of the Kyrgyz Republic during lactation period. Procedia - Social and Behavioral Sciences 195: $2683-$ 2688. DOI:10.1016/j.sbspro. 2015.06.479.

Medina M, Fernandez F, Saad S, Rebuffi S, Yapur J. 2004. Inmunoglobulinas G De Cadenas Pesadas En La Leche De Los Camélidos Sudamericanos. Mastozoología Neotropical / J. Neotrop. Mammal.; 11(1): 19-26. 
Nazzaro S. 2010. Isolation of components with antimicrobial property from the donkey milk: A preliminary study. The Open Food Science Journal. 4: 43- 47.

Nikkhah A. 2011. Science of camel and yak milks: Human nutrition and health perspectives. Food and Nutrition sciences, 2: 667-673. DOI: 10.4236/fns.2011.26092.

Perna A, Intaglietta I, Simonetti A, Gambacorta E. 2015. Donkey Milk for Manufacture of Novel Functional Fermented Beverages, Journal of Food Science, 80 (6): 1352-1359.

Pieszka M, Łuszczyńskil J, Zamachowska M, Augustyn R, Długosz B, Hędrzak M. 2016. Is mare milk an appropriate food for people? - A review. Annals of Animial Science, 16 (1): 33-51. DOI:10.1515/aoas-2015-0041.

Polidori P, Vincenzetti S.2013. Use of donkey milk in children with cow's milk protein allergy. Foods, 2: 151-159. DOI: $10.3390 /$ foods2020151.

Potočnik K, Gantner V, Kuterovac K, Cividini A. 2011. Mare's milk: composition and protein fraction in comparison with different milk species. Mljekarstvo, 61 (2): 107-113.

Ramet J P. 2001. The Technology of Making Cheese from Camel Milk (Camels dromedary). Animal Production and Health Paper. No. 113, FAO, Rome, Italy.

Sakandar AH, Ahmad S, Perveen R, Aslam KW, Shkeel A, Sadiq FA, Imran M. 2018. Progress in Nutrition, 20: 15-29. DOI: 10.2351/pn.v20il-S5318.
Salamon Sz, Csapó J, Lóki K, Csapó-Kiss Z. 2009. Composition of mare's colostrum and milk. II. Protein content, amino acid composition and contents of macro- and micro-elements. Acta Universitatis Sapientiae, Alimentaria, 2: 133-148.

Singh R, Mal G, Kumar D, Patil NV. 2017. Camel milk: An important natural adjuvant. Agric Res, 6(4): 327-340. DOI: 10.1007/s40003-17-0284-4.

Tafaro A, Magrone T, Jirillo F, Martemucci G, D'Alessandro AG, Amati L, Jirillo E. 2007.

Immunological properties of donkey's milk: its potential use in the prevention of atherosclerosis.

Curr Pharmaceut Design, 13: 3711-3717. DOI: 10.2174 /138161207783018590.

Taufik E, Ganzorig K, Nansalmaa M, Fukuda R, Fukuda R, Fukuda K, Saito T, Orashima T. 2014. Chemical characterization of saccharides in the milk of a reindeer (Rangifer tarandus). International Dairy Journal, 34: 104108. DOI: 10.1016/j.idairyj.2013.07.012.

Tsakalidou E, Khlonaris S. 2012. Processing of Non-Cow's Milk - Technological Challenges and Economic Perspectives. IDF World Dairy Summit. Pp: 1-45.

Wiener G, Jialnlin H, Ruijun L. 2003. The yak second edition. Food and Agriculture Organization of the United Nations Regional Office for Asia and the Pacific, Bangkok, Thailand. RAP Publication. ISBN: 92-5-104965-3

Yagil R. 1982. Camels and camel milk. Animal Production and Health Paper, No. 26, FAO, Rome. 